\title{
PERAN LABORATORIUM DALAM DIAGNOSIS DAN PENATALAKSANAAN KASUS KASUS PENYAKIT TROPIK DAN INFEKSI
}

\section{(THE ROLE OF LABORATORY MEDICINE IN DIAGNOSIS AND MANAGEMENT OF TROPICAL AND INFECTIOUS DISEASE PATIENTS)}

\author{
Teguh Wahju Sardjono*, Gatoet Ismanoe* ${ }^{* *}$ Edi Widjayanto***. \\ *Laboratorium Parasitologi FK Unibraw Malang \\ **Laboratorium/Bagian IImu Penyakit Dalam FK Unibraw / RS dr. Saiful Anwar Malang \\ *** Laboratorium/Bagian Patologi Klinik FK Unibraw / RS dr. Saiful Anwar Malang
}

\begin{abstract}
Infectious disease is still a health problem in the world, especially in tropical and developing countries, including Indonesia. The diagnosis of tropical disease cases mostly are still based on the main of clinical symptoms, that is fever. Among 900 fever patients, $21 \%$ of the disease were diagnosed by clinical examinations, $35 \%$ by laboratory tests and $40 \%$ were diagnosed as fever of unknown origin (FUO). One forth of the FUO patients were definitively diagnosed after specific laboratory tests, but the use of the specific tests in daily practice were relatively rare. The tests ordered by physicians to the Department of Central Clinical Laboratory Dr. Saiful Anwar Hospital Malang, are mostly hematology and blood chemical tests (59.54\% and 21.52\%). Specific tests for microbiology and parasitology were only $3.15 \%$ and $0.46 \%$ respectively. Fever patients who not definitively diagnosed, often received unnecessary treatments or medications (over-treatment), those are actually dangerous to them. To improve the quality of clinical management, the traditional laboratory service should be changed to be the interactive laboratory service. It needs a role, understanding and good collaboration between clinical practitioners who know the basic sciences and the pre/para-clinical scientists who interest to the clinical phenomenon. The aim of the change is to get the more scientific, ethical and professional medical services.
\end{abstract}

Key words: Laboratory medicine, diagnosis, management, infectious disease

\section{PENDAHULUAN}

\subsection{Latar Belakang}

Penyakit infeksi sampai saat ini masih menjadi masalah kesehatan utama di dunia. Hal ini disebabkan karena penyakit yang disebabkan oleh infeksi berbagai jenis bakteri, virus, jamur maupun parasit masih merupakan penyebab kesakitan dan kematian tertinggi, terutama di negara-negara tropik. Masalah ini menjadi semakin komplek dengan timbulnya berbagai jenis penyakit infeksi yang termasuk: "The New Emerging and Reemerging Infectious Diseases". Ternyata kelompok penyakit ini telah menjadi perhatian khusus di berbagai negara di dunia, dan sempat menghantui negara-negara maju, seperti Jepang, USA, Australia dan negara-negara di benua Eropah. Demikan juga halnya di Indonesia. Beberapa penyakit yang telah dikenal sejak lama dan masih tetap menjadi masalah seperti tuberkulosis, malaria dan demam berdarah, akhir-akhir ini menunjukkan kecenderungan peningkatan angka kesakitan maupun kematian. Di sisi lain, berbagai penyakit yang secara klinis hanya menunjukkan gejala ringan dan dianggap tidak mengancam jiwa (non life threatening) seperti malaria tanpa penyulit, toxoplasmosis dan infestasi cacing, sering kali tidak terdiagnosis, bahkan terlepas dari perhatian kita sehingga tidak tertangani dengan baik. Sebagai contoh, di berbagai daerah Indonesia di luar Jakarta, angka kejadian infestasi cacing usus masih berkisar antara $40 \%$ - $60 \%$ untuk semua golongan umur dan $60 \%-90 \%$

Jurnal Kedokteran Brawijaya, Vol. XX, No.1, April 2004.

Korespondensi: Teguh Wahyu Sardjono; Lab. Parasitologi FK

Unibraw; Jl. Veteran Malang-65145; telp (0341) 580993, 567192 fax (0341)564755 di kalangan anak-anak sekolah $(1,2)$, namun demikian penanggulangan terhadap penyakit kecacingan terkesan seolah diabaikan, padahal hal ini sangat berpengaruh terhadap tingkat kecerdasan anak-anak dan produktivitas tenaga kerja. Kerugian yang dapat dihitung akibat infestasi cacing usus diperkirakan setara dengan 13.084.337 kg. beras atau Rp. 94.207.230.000 per tahun $(1,3)$.

Diagnosis dan penatalaksanaan penderita penyakit infeksi dalam praktek sehari-hari masih sering berdasarkan gejala klinis terutama febris atau demam. Febris merupakan gejala utama dari berbagai jenis penyakit infeksi, namun pada kenyataannya lebih dari separoh penderita febris, sembuh dengan sendirinya atau sembuh secara "kebetulan". Pada penelitian multisenter yang dilakukan oleh Petit (1994) terhadap 900 penderita febris, $21 \%$ di antaranya penyakitnya dapat didiagnosis melalui pemeriksaan klinis, 35\% melalui pemeriksaan laboratoris, $4 \%$ ternyata tidak ditemukan adanya infeksi dan $40 \%$ terpaksa didiagnosis sebagai demam yang tidak diketahui sebabnya atau FUO (Fever of Unknown Origin) (4). Dari 40\% penderita FUO tersebut, 17\% sembuh dengan sendirinya, tetapi $23 \%$ sisanya justru menjadi makin berat dan parah, bahkan jatuh dalam keadaan sepsis dan akhirnya meninggal (4). Seperempat dari kasus-kasus FUO baru diketahui penyebabnya setelah melalui pemeriksaan laboratorium khusus (5). Penderita febris tanpa diagnosis yang pasti seringkali memperoleh tindakan yang tidak diperlukan atau pengobatan yang berlebihan (overtreatment). Hal ini tentu saja sangat merugikan penderita ditinjau dari berbagai aspek.

Dalam makalah ini dikemukakan sebuah opini tentang peran laboratorium dalam proses diagnosis dan penatalaksanaan penyakit infeksi saat ini dan di masa mendatang. 


\subsection{Kedudukan Laboratorium Dalam Proses Pananganan Penderita Saat Ini}

Dalam bidang Kedokteran, peran dan kedudukan laboratorium medik dalam proses penanganan penderita di dalam maupun di luar Rumah Sakit saat ini masih berada pada lini belakang. Laboratorium hanya diminta untuk dapat menghidangkan data kualitatif, yaitu ada atau tidaknya penyakit yang dicurigai oleh klinisi; atau data kuantitatif berupa angkaangka yang menyatakan bahwa pasien tersebut sakit atau tidak. Interpretasi data seakan-akan mutlak berada di tangan klinisi. Pihak laboratorium hampir tidak pernah ikut serta dalam penentuan diagnosis, apalagi sampai kepada penatalaksanaan penderita. Jadi Laboratorium seolah-olah hanya sebagai koki yang diminta memasak pesanan dokter. Si "koki" hampir tidak punya hak menawarkan alternatif masakan lain seandainya menu tadi tidak cocok dengan harapan. Dalam praktek sehari-hari di Rumah Sakit, unit laboratorium hanya menerima bahan pemeriksaan yang dikirim dokter ruangan atau poliklinik. Tidak jarang terjadi spesimen atau bahan pemeriksaan dikirim ke Laboratorium tanpa keterangan yang jelas, sehingga bila terjadi kesalahan atau ketidak sesuaian antara kondisi klinis dengan hasil laboratorium, tidak bisa dideteksi sebabnya. Akibatnya data tersebut tidak dipakai atau dibuang, dan diagnosis tetap tidak dapat ditegakkan.

Beberapa data berikut menunjukkan berbagai jenis dan jumlah pemeriksaan laboratorium yang dilakukan di RSUD dr Saiful Anwar Malang. (Gambar 1,2,3, dan Tabel 1.) Dari data tersebut terlihat bahwa permintaan pemeriksaan laboratorium lebih sering dilakukan berdasarkan prosedur rutin, dan belum berdasarkan alasan atau indikasi khusus (6).

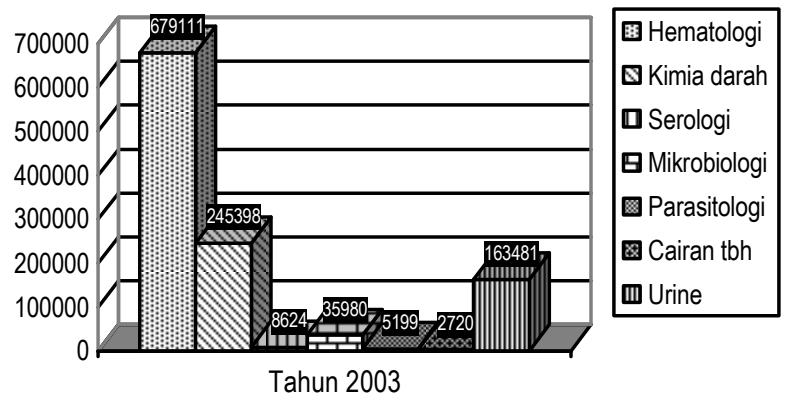

Gambar 1. Jenis dan jumlah pemeriksaan laboratorium di Instalasi Lab. Sentral RSSA tahun 2003

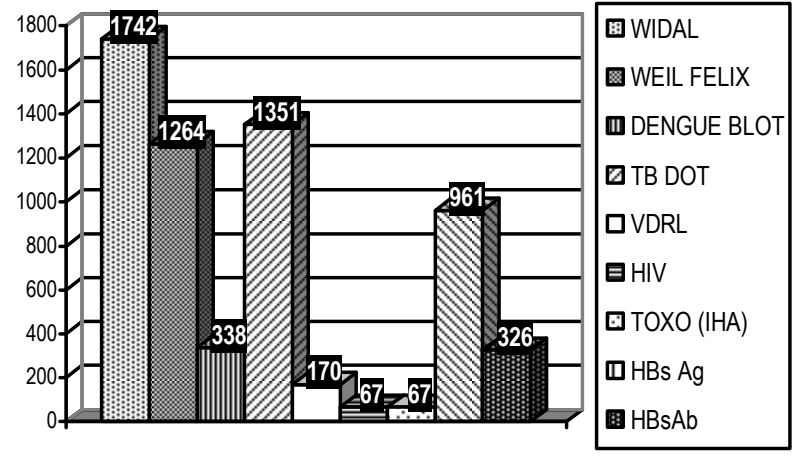

Gambar 2. Jenis dan jumlah pemeriksaan serologis di Instalasi Lab. Sentral RSSA tahun 2003.

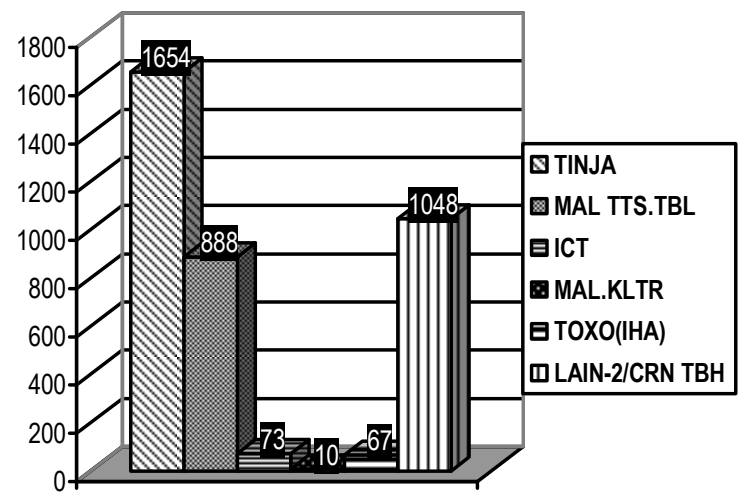

Gambar 3. Jenis dan jumlah pemeriksaan parasitologis di Instalasi Lab. Sentral RSSA tahun 2003.

\section{PEMBAHASAN}

\subsection{Tahap-Tahap Pemeriksaan Laboratorium}

Setiap tindakan atau penatalaksanaa pemeriksaan laboratorium pada hakekatnya harus melewati 3 tahap utama, yaitu tahap pre-analitik (input), analitik (process) dan post-analitik (output). Setiap tahap harus menjawab pertanyaan yang spesifik (Gambar 4).

1. Input :

- Apakah tes yang diminta sesuai dengan kondisi klinik?

- Apakah jenis bahan dan waktu pengambilannya sudah benar?

2. Proses:

- Apakah prosedur pemeriksaan sudah dilakukan dengan benar?

- Apakah hasil yang diperoleh cukup akurat/dapat dipercaya?

- Apakah waktu pelaksanaan terlalu lama (turn around time needs of clinicians)?

3. Output:

- Apakah hasil pemeriksaan cukup dapat diinterpretasikan?

- Apakah hasil pemeriksaan cocok dengan kondisi klinis? 
- Apakah data tidak berlebihan dan menimbulkan kebingungan?

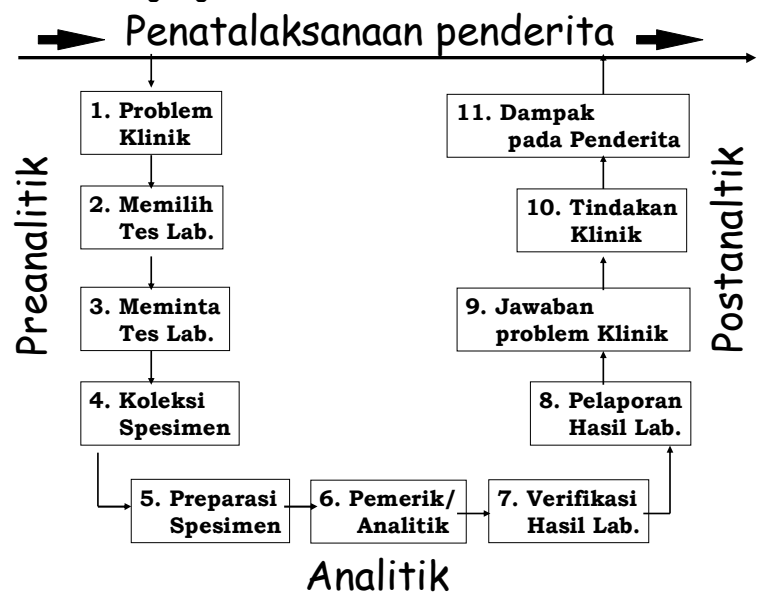

Gambar 4 : Tahap-tahap yang dilalui dalam penatalaksanaan
penderita

Integrasi yang optimal dari ke tiga proses tersebut akan menghasilkan data pemeriksaan yang sangat bernilai dan bermanfaat. Sebaliknya, hasil pemeriksaan akan sia-sia atau kecil nilainya bila dilakukan hanya atas dasar permintaan yang sebenarnya tidak diperlukan, bahkan seringkali merugikan penderita. Pemeriksaan yang diperoleh dengan prosedur pemeriksan yang rumit, canggih dan mahal bila dilakukan bukan atas dasar indikasi yang tepat dapat diinterpretasikan salah atau bahkan tidak bernilai sama sekali (7).

\subsection{Bagaimana Meningkatkan Peran Laboratorium Dalam Diagnosis Penyakit Infeksi}

Telah disebutkan bahwa dalam penatalaksanaan penderita penyakit infeksi, diagnosis sering hanya didasarkan atas gejala klinik, dan pemeriksaan laboratorium lebih banyak atas dasar permintaan rutin. Beberapa data laboratorium rutin memang dapat dijadikan parameter untuk mendiagnosis penyakit infeksi, tetapi sifatnya tidak langsung (indirect diagnosis) dan tidak spesifik. Sebagai contoh, dari hasil pemeriksaan hematologi, kadar hemoglobin yang rendah disertai eosinofil yang tinggi menunjukkan kemungkinan adanya infestasi cacing. Netrofilia atau lekositosis mengindikasikan adanya infeksi bakteri, leukopenia pada umumnya terjadi pada infeksi virus. Thrombositopenia pada umumnya dijumpai pada penderita demam berdarah, dapat juga terjadi pada keadaan sepsis yang berat. LED yang meningkat dapat dijumpai pada infeksi akut. Kadar CRP juga meningkat lebih dari 10 kali pada infeksi bakteri akut. Kadar SGOT/SGPT yang tinggi merupakan indikator penting pada penyakit hepatitis (8).

Sebenarnya laboratorium dapat berperan lebih dominan, nyata dan menghasilkan data yang akurat dan spesifik sehingga menghasilkan diagnosis pasti (definitive diagnosis), bila prosedur dilakukan secara rasional. Metode pemeriksaan yang canggih belum tentu menjamin kepastian diagnosis. Sebaliknya pemeriksaan sederhana seperti hapusan atau pengecatan langsung dari sediaan darah, sputum atau feses saja sudah dapat memastikan diagnosis karena ditemukan organisme penyebab penyakitnya. Pada kasus-kasus tertentu pemeriksaan sederhana masih merupakan tes baku untuk diagnosis penyakit (gold standard), misalnya malaria, kuman tahan asam, difteri dsb. Keberadaan organisme juga dapat dibuktikan dengan metoda yang lebih spesifik, misalnya kultur, inokulasi pada hewan coba ataupun pemeriksaan serologi. Dengan metoda serologi dapat dideteksi adanya antigen atau antibodi terhadap patogen yang dicurigai, namun nyatanya pemeriksaan laboratorium yang spesifik ini relatif masih jarang diminta oleh para klinisi. (Gambar 1, 2, 3 dan Tabel 1).

Untuk mengatasi kesenjangan tersebut serta meningkatkan peran laboratorium perlu disadari bahwa dalam penatalaksanaan penderita selayaknya pasien diperlakukan secara menyeluruh/holistic. Seorang Clinical laboratory scientist harus terlibat dalam proses, sejak dari mengapa dan bagaimana tes-tes tersebut diminta, faktor-faktor apa saja yang dapat mempengaruhi hasil tes pada setiap tahap pemeriksaan sampai dengan bagaimana variabel-variabel pengganggu tersebut dapat dikurangi (preanalitik, analitik, postanalitik) (Gambar 4). Bila sampai saat ini penggunaan laboratorium masih dirasakan belum optimal, maka dapat dianalisis beberapa kemungkinan penyebabnya pada setiap tahap pemeriksaan, misalnya:

- Input (preanalytic): tes yang diminta tidak cocok dengan kondisi klinik atau bahan dan waktu pengambilannya tidak benar.

- Process (analytic): preparasi specimen dan prosedur kurang benar, peralatan terbatas, ketrampilan pelaksana kurang, sehingga hasil tes tidak akurat atau waktu untuk menunggu hasil terlalu lama (turn around time needs).

- Output (postanalytic): Hasil tes tidak dapat menjawab problem klinik, sehingga diabaikan atau bahkan sering kali dibuang.

\subsection{Ciri-Ciri Laboratorium Tradisional dan Laboratorium Interaktif}

Saat ini perkembangan pelayanan laboratorium dituntut untuk terus berkembang dari laboratorium yang masih bersifat

Tabel 1. Hasil kultur beberapa bahan pemeriksaan di Laboratorium Mikrobiologi Instalasi Lab. Sentral RSSA tahun 2003.

\begin{tabular}{lccccccccccc}
\hline \multirow{2}{*}{ Bahan } & $\Sigma$ & \multicolumn{2}{c}{ Steril } & \multicolumn{2}{c}{ Kultur Positif } & \multicolumn{2}{c}{ Kuman Dominan1 } & \multicolumn{2}{c}{ Kuman Dominan 2 } & \multicolumn{2}{c}{ Kuman Dominan 3 } \\
\cline { 2 - 13 } & & $\mathrm{n}$ & $\%$ & $\mathrm{n}$ & $\%$ & Nama & $\%$ & Nama & $\%$ & Nama & $\%$ \\
\hline Darah & 808 & 690 & 85,40 & 108 & 13,37 & Staph coag neg & 18,52 & K.pneumoniae & 12,96 & S.marcescens & 11,11 \\
Urine & 1528 & 904 & 59,16 & 606 & 39,66 & E.coli & 29,54 & Ps.aeruginosa & 13,86 & A.anitratus & 10,07 \\
Pus & 1085 & 186 & 17,14 & 884 & 81,47 & Staph coag neg & 16,29 & Staph coag pos & 13,24 & E.coli & 13,12 \\
Sputum & 766 & 9 & 1,17 & 732 & 95,56 & K.pneumoniae & 20,63 & A.anitratus & 15,03 & Staph coag neg & 12,84 \\
Faeces & 495 & 49 & 9,90 & 444 & 89,70 & E.coli & 34,46 & P.mirabilis & 9,46 & K.pneumoniae & 8,56 \\
\hline
\end{tabular}


tradisionil menuju laboratorium interaktif. Adapun tahap-tahap yang terjadi baik di laboratorium laboratorium tradisional maupun interaktif pada dasarnya terdiri dari 3 fase seperti yang telah disebutkan di depan, yaitu fase input (pre-analitik), proses (analitik) dan output (post-analitik). Pada umumnya laboratorium tradisional hanya menghasilkan data berupa nama atau angka. Proses yang terjadi adalah, bahan pemeriksaan diterima, jenis tes yang diminta dikerjakan, kemudian keluar hasil. Dengan mengadopsi kontrol kualitas dan prinsip-prinsip otomatisasi, laboratorium ini dapat memproduksi data yang baik dengan modal yang sedikit. Laboratorium tradisional biasanya lebih bertolak pada sistem "fee-for-service payment". Dengan demikian semakin banyak tes yang dilakukan semakin banyak
Bertolak dari hal-hal di atas, maka sudah saatnya terjadi pergeseran dari laboratorium yang bersifat tradisional menuju laboratorium yang bersifat interaktif. Untuk itu maka diperlukan usaha yang sungguh-sungguh untuk melakukan pembaharuan yang meliputi banyak segi. Dari segi sistem dan struktur organisasi, diperlukan pengertian dan keluasan cara pandang dari semua pihak dan disiplin ilmu terutama para pemegang kebijakan. Untuk pengadaan peralatan laboratorium yang lengkap dan memenuhi harapan, serta untuk peningkatan kemampuan dan ketrampilan SDM melalui pelatihan atau pendidikan khusus, tentu saja memerlukan dana yang tidak sedikit. Kesungguhan untuk melakukan pembaharuan juga harus dimiliki oleh seluruh pihak yang terkait. Terciptanya kerjasama lintas UPF

\section{Traditional Vs Interactive Laboratory}

\begin{tabular}{|c|c|}
\hline Traditional Laboratory & Interactive Labor \\
\hline $\begin{array}{l}\text { Test Ordered } \\
\text { Input }\end{array} \sqrt{\text { Test Performed }} \sqrt{\text { Test Interpreted }}$ & \\
\hline $\begin{array}{l}\text { The traditional Lab } \\
\text { is isolated from what tests are } \\
\text { ordered (input) and how their } \\
\text { results are interpreted (output) }\end{array}$ & $\begin{array}{l}\text { In the Interactive Lab, } \\
\text { Laboratorians (CLS, MT) and clinicians } \\
\text { interact to improve how tests are; } \\
\text { ordered, performed, and interpreted }\end{array}$ \\
\hline fee-for-service payment & $\begin{array}{l}\text { prospective or capitated method of } \\
\text { payment }\end{array}$ \\
\hline & $\begin{array}{l}\text { CLS, Clinical Lab Scientist } \\
\text { MT, Medical Technologist } \\
\text { Barr JT. (1999). Clinical Laboratory Utilization; Rationale. } \\
\text { In (Davis B, et all, edss Principles of Clinical Laboratory } \\
\text { Utilization and Consultation. }\end{array}$ \\
\hline
\end{tabular}

\section{Gambar 5: Pada Laboratorium tradisional, tes yang diminta (input) terpisah dengan interpretasi hasil tes (output). Pada laboratorium interaktif sudah ada interaksi antara klinisi dengan ahli laboratorium dan teknisi yang melakukan pemeriksaan.}

juga bayaran yang diterima oleh laboratorium. Di samping itu para klinisi mempunyai akses yang tidak terbatas, sehingga sangat mungkin terjadi permintaan tes laboratorium yang sebenarnya tidak diperlukan untuk diagnosis dan terapi (overuse of laboratory tests) (7).

Di laboratorium interaktif, para ahli mengembangkan peranannya di luar hal yang biasa terjadi di laboratorium tradisional, yaitu melibatkan dirinya ke dalam seluruh fase atau rangkaian proses yang menghasilkan informasi laboratorium, termasuk pemanfaatan seluruh sumber daya yang ada di laboratorium. Digambarkan bahwa para ahli di laboratorium berinteraksi dan bekerja sama dengan klinisi untuk meningkatkan kebenaran tes yang diminta (pre-analitik), kebenaran prosedur pelaksanaan teknis (analitik) serta kebenaran di dalam menarik kesimpulan oleh klinisi (post analitik). Laboratorium interaktif menganut sistem "prospective or capitated method of payment". Dengan sistem ini, laboratorium atau dokter menerima sejumlah anggaran yang harus mencakup semua pelayanan. Perbedaan latar belakang ekonomi ini menyebabkan perbedaan fungsi yang sangat menyolok di antara keduanya. (7), namun demikian, karena orientasi bisnis, prinsip ekonomi yang berlaku di laboratorium tradisional agaknya sulit untuk dihindari (gambar 5). membutuhkan keterbukaan dan kebesaran jiwa dari semua pihak, dengan azas saling menghormati disiplin ilmu masing-masing, bahwa pada dasarnya ilmu kedokteran tidak dapat dikotak-kotak secara tegas.

\section{4 "Clustering" dan Integrasi Profesi Kedokteran.}

Di dalam dunia kedokteran sampai saat ini masih terasa adanya perbedaan antara ilmu-ilmu kedokteran klinik dan ilmuilmu kedokteran pre/paraklinik. Di beberapa rumah sakit perbedaan ini masih jelas sekali batasnya, sehingga kedua kelompok disiplin ilmu tersebut seolah-olah dipagari oleh tembok yang kuat, setebal "the Great Wall" di China.

Dengan makin berkembangnya ilmu pengetahuan di bidang kedokteran, khususnya ilmu kedokteran molekuler (Molecular Medicine), makin disadari bahwa pada dasarnya kedua kelompok disiplin ilmu tersebut tidak dapat dipisahkan satu dengan lainnya. Para dokter yang bekerja di klinik dan secara langsung berhadapan dengan pasien setiap saat akan bertemu dengan fenomena-fenomena klinis yang tidak diketahui latar belakangnya. Dasar patogenesis dan patofisiologi suatu penyakit ternyata sudah tidak dapat lagi diterangkan berdasarkan teori lama. Konsep tentang penyakit tertentu yang ternyata tidak cocok dengan kondisi penderita, menuntut para peneliti untuk mencari 
teori lain yang lebih mendasar (back to basic). Timbulnya masalah-masalah baru di bidang kedokteran (Kedokteran Antariksa, Kelautan, Pariwisata dII) memerlukan penjelasan yang berasal dari bidang ilmu kedokteran dasar. Di sinilah para ahli laboratorium yang berasal dari IImu Kedokteran Dasar dituntut peranannya, sehingga IImu Anatomi, Histologi, Faal dan Biokimia yang dahulu sempat dianggap sebagai ilmu statis, sekarang dituntut untuk lebih berperan dalam menerangkan fenomenafenomena tersebut. Laboratorium Patologi Anatomi, Patologi Klinik, Mikrobiologi dan Parasitologi juga dituntut untuk lebih aktif mencari konsep-konsep yang baru. Mereka harus dapat memecahkan fenomena-fenomena klinik yang dijumpai itu secara substansial dan lebih dapat dipertanggung jawabkan, bahkan sampai ke tingkat molekuler (9). Munculnya penyakit-penyakit yang tergolong the New Emerging dan Re-emerging Infectious Diseases menunjukkan bahwa banyak patogen yang berasal dari mikro-organisme yang baru ditemukan, atau sudah pernah dikenal tetapi sekarang menunjukkan sifat-sifat virulensi yang berbeda.

Dari uraian tersebut di atas, dikemukakan hadirnya penengah, yaitu Laboratorium Medik yang berfungsi sebagai jembatan antara kelompok-kelompok ilmu kedokteran tersebut. (10). Laboratorium Medik yang anggotanya adalah para peneliti dan ilmuwan di bidang Mikrobiologi, Parasitologi, Patologi dan Patologi Klinik, akan bekerja bersama dalam mengembangkan laboratorium untuk memecahkan masalah sampai tingkat seluler atau bahkan molekuler (10). Dengan ilmu dan keahlian masingmasing, mereka saling bertukar pikiran dan menyatukan pendapat dan pemikiran mereka guna memperoleh jawaban atas problema penyakit yang belum terjawab rahasianya. Dengan demikian yang diharapkan adalah di masa mendatang IImu Kedokteran tidak lagi terbagi dalam kelompok secara tegas, tetapi sudah berintegrasi menjadi satu kesatuan yang terdiri dari berbagai disiplin ilmu. (Gambar 6).

\subsection{Penatalaksanaan Penderita Pada Berbagai Tingkat Pengkajian Penyakit.}

Ide Integrasi Profesi Kedokteran seperti yang telah dikemukan di atas nampaknya memang ideal, tetapi dalam praktek mungkin masih sulit dilaksanakan. Hal ini disebabkan oleh karena berbagai keterbatasan yang memang tidak dapat dihindari. Bagaimanapun fenomena-fenomena klinik akan tetap dihadapi oleh para profesional yang bekerja di klinik, sehingga pengkajian penyakit pada tingkat klinik mungkin hanya terbatas untuk ilmu-ilmu kedokteran klinik. Apabila pengkajian pada tingkat klinik tersebut belum mampu menjawab masalah, maka diperlukan pengkajian lebih lanjut sampai ke tingkat laboratorik, tingkat molekuler atau ke tingkat yang lebih dalam lagi. Sampai saat ini sudah terbukti bahwa melalui berbagai penelitian dan pengkajian penyakit, ilmu kedokteran molekuler telah mampu menjawab hampir semua fenomena penyakit, termasuk berbagai jenis penyakit infeksi. Pengkajian penyakit di tingkat laboratorik mungkin sudah mampu menerangkan timbulnya berbagai jenis mikroba ataupun menemukan berbagai galur yang baru dengan sifat-sifat biologis termasuk virulensinya yang juga baru, tetapi ternyata rahasia timbulnya galur dan sifat biologis dan virulensi yang baru itu baru dapat dijelaskan setelah melalui penelitian dan pendekatan pada tingkat biomolekuler (11).

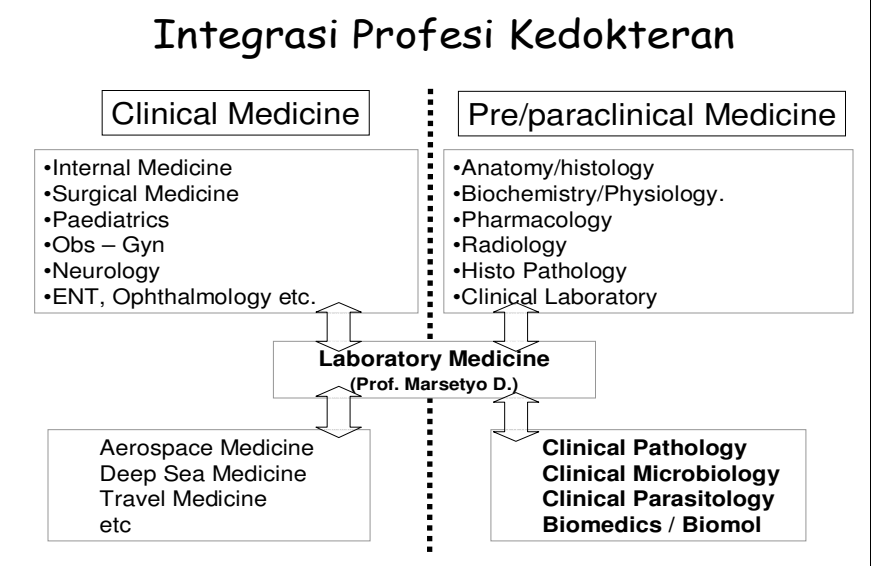

Gambar 6. Clustering dan integrasi profesi kedokteran

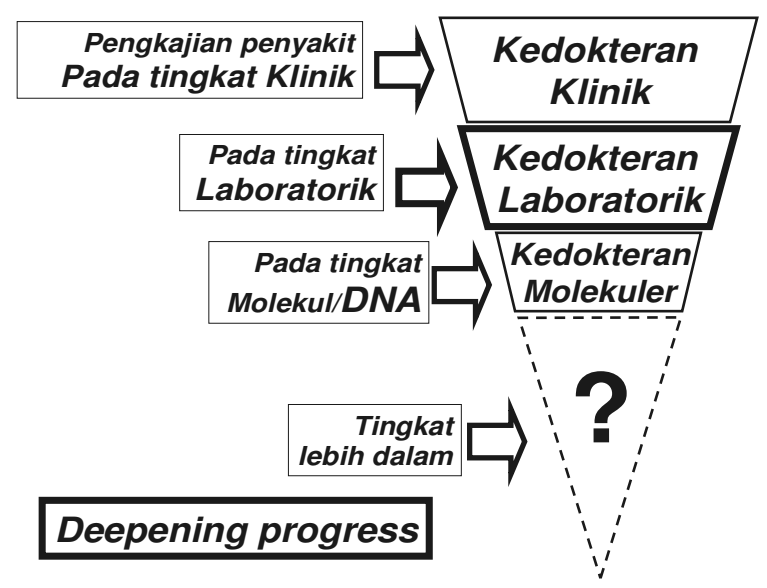

Gambar 7. Pendekatan dan pengkajian penyakit pada berbagai tingkat keilmuan

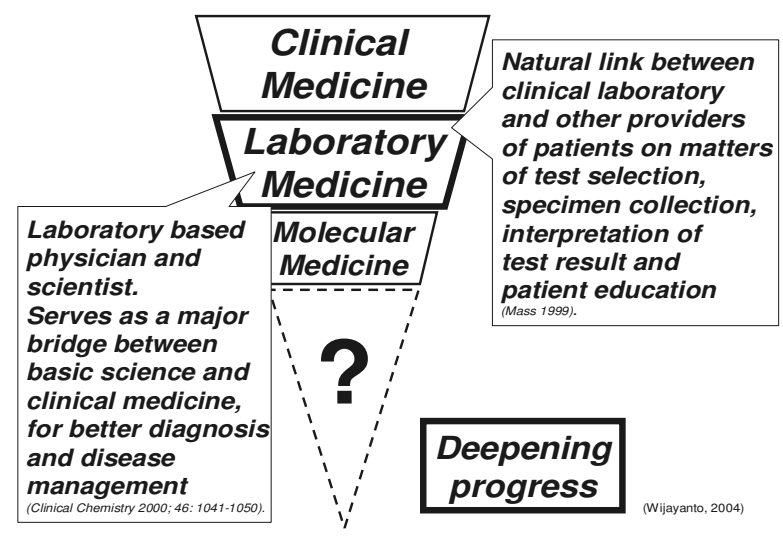

Gambar 8. Peran Laboratorium sebagai perantara yang menjembatani Kedokteran Klinik dan Kedokteran Molekuler, atau tingkat yang lebih dalam

Bertolak dari hal-hal tersebut di atas, maka ide ini dapat dikembangkan lebih lanjut, sehingga di masa mendatang Laboratorium yang anggotanya adalah para dokter di bidang masing-masing, benar-benar dapat menjadi perantara yang 
menjembatani ilmu-ilmu dasar dengan ilmu-ilmu klinik. Dalam bidang penyakit infeksi maka keberadaan dan peran Ahli Mikrobiologi, Ahli Parasitologi dan Ahli Patologi Klinik sangat diperlukan. Mereka perlu dilibatkan dalam pengelolaan pasien, sejak dari pemilihan jenis pemeriksaan pengambilan spesimen, proses pemeriksaan, sampai dengan interpretasi hasil.

Dengan adanya hubungan dan kerjasama yang baik antara para dokter dan praktisi di klinik dengan para ahli yang ada di Laboratorium, masing-masing dengan seluruh anggotanya maka akan dapat terbentuk suatu kelompok kerja yang kompak. Di sini diperlukan keberadaan para praktisi klinis yang memahami ilmu-ilmu dasar dan para ilmuwan pre/paraklinik yang memahami fenomena-fenomena klinik. Seorang dokter tidak saja dituntut untuk mempunyai kemampuan diagnosis yang tepat, tetapi juga kemampuan untuk memberi penjelasan secara ilmiah serta mengelola penderita dengan penuh tanggung jawab, sehingga terwujud peningkatan kualitas pelayanan terhadap penderita adalah pelayanan medik yang scientific, ethical dan professional. (Gambar 9).

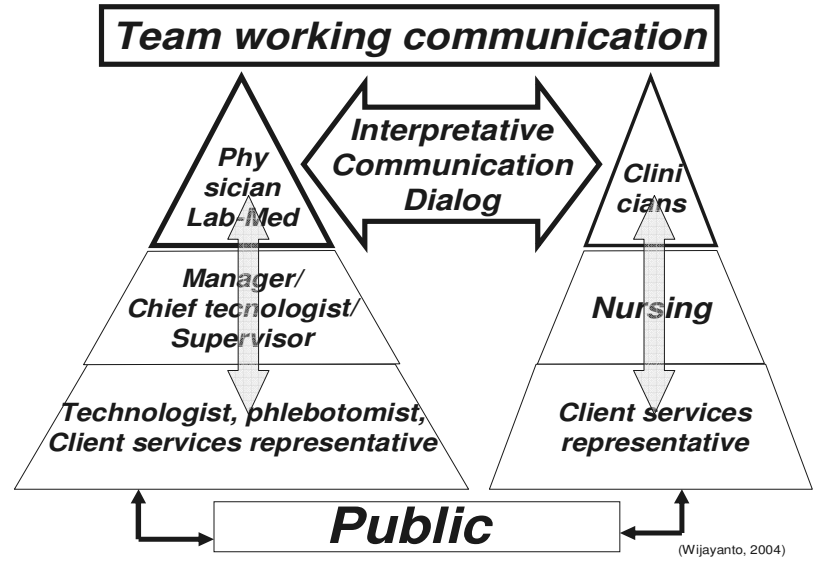

Gambar 9. Kelompok kerja yang diharapkan terjalin atas

\section{kerja sama semua pihak.}

\section{PENUTUP}

Penyakit infeksi masih menjadi masalah kesehatan utama di dunia, khususnya di negara-negara tropik dan berkembang termasuk indonesia. Sampai saat ini diagnosis penyakit infeksi masih sering hanya berdasarkan atas gejala utama, yaitu febris. Penanganan penderita febris tanpa diagnosis yang jelas sering menyebabkan tindakan atau pemberian obat yang berlebihan (overtreatment), sehingga menimbulkan penyakit baru, resistensi obat dan hal lain yang merugikan penderita. Pelayanan laboratorium tradisional sudah saatnya bergeser ke arah laboratorium interaktif. Penggunaan laboratorium yang spesifik untuk diagnosis penyakit infeksi masih belum optimal, bahkan masih minimal dibandingkan dengan pemeriksaan labotatorium rutin lain. Diperlukan sosialisasi untuk menyamakan persepsi di antara cabang-cabang ilmu kedokteran klinik dan pre/paraklinik untuk, sehingga laboratorium dapat lebih berperan secara nyata dalam penatalaksanaan penderita.

\section{DAFTAR KEPUSTAKAAN}

1. Suyudi A. Opening Speech of Minister of Health of the Republic of Indonesia on the Opening Ceremony of International Conference on Controlling Disease Due to Soil Transmitted Helminths, Bali. Indonesia; February 2000.

2. Margono SS. Important Human Helminthiasis in Indonesia. International Conference on Controlling Disease Due to Soil Transmitted Helminths, Bali. Indonesia. February 2000.

3. Yusuf B. Policy on Controlling Helminthiasis in Indonesia. Acting Director DTDC, Directorate General CDC \& EH. Minister of Health Republic of Indonesia. 2000.

4. Petit PL. Analysis of Infectious Diseases in Rural Areas. Afr. J Health. Sci. 1994: 1 (3): 108-111.

5. Pohan HT. Fever of Unknown Origin. Dalam Widodo D dan Pohan HT. Bunga Rampai Penyakit Infeksi. Divisi Penyakit Tropik dan Infeksi Departemen IImu Penyakit Dalam Fakultas Kedokteran Universitas Indonesia. Jakarta; 2004: 124-40.

6. Instalasi Laboratorium RSSA. Catatan Hasil Pemeriksaan Laboratorium selama tahun 2003. RSUD dr. Saiful Anwar Malang; 2003.

7. Barr JT. Clinical Laboratory Utilization; Rationale. In Davis BG, et al., eds. Principles of Clinical Laboratory Utilization and Consultation.. Philadelphia: W.B Saunders Company; 1999.

8. Pohan HT. Manfaat Klinis Pemeriksaan Laju Endap Darah. Dalam Widodo D dan Pohan HT. Bunga Rampai Penyakit Infeksi. Divisi Penyakit Tropik dan Infeksi Departemen IImu Penyakit Dalam Fakultas Keokteran Universitas Indonesia. Jakarta; 2004: 12-17.

9. Mass D. Consulting as a Profesional Role for the Clinical Laboratory Scientist. In Davis BG, et al., eds. Principles of Clinical Laboratory Utilization and Consultation. Philadelphia: WB Saunders Company; 1999.

10. Donosepoetro M. Management Pendidikan: Dokter Spesialis Patologi Klinik. Kongres Nasional IV Perhimpunan Dokter Spesialis Patologi Klinik. 2001.

11. Widjayanto E. Laboratory Medicine Scientist, Sebuah Renungan. Rapat Kolegium Patologi Klinik Indonesia, Jakarta. 2002. 